\title{
Research on the Effect on Tax Burden of Earning Management Based on Lipschitz Theory
}

\author{
Yunzhao Lu \\ Department of Economics and Trade \\ Fuzhou University of International Studies and Trade \\ Fuzhou, China 350202
}

\begin{abstract}
Based on the features of Chinese market and Chinese institution, this paper intends to study the relationship between earnings management and tax burden by using the account error correction data. As is revealed in the study, the fundamental goal of the earnings management in the listed companies is to allegedly inflate earnings. However, the majority of the companies won't pay the extra taxes and instead, they decrease tax reporting. Little tax restrictions have been attached to the accounting earnings, Therefore tax reduction may be attributed to the way rather than the goal of earnings management. The implication of the phenomena is that analysis on book-tax differences may be the useful tool for supervisors to investigate the earnings management behaviour, for investors and CPA to appraise the quality of accounting information, and for tax sections to supervise the tax report.
\end{abstract}

Keywords-Earnings Management; Tax Burden; Accounting Error Correct; Book-tax Differences

\section{INTRODUCTION}

The relationship between earnings management and the tax burden is the most basic and important issue concern about capital market supervision and the coordination between tax laws and financial accounting rules. With the continuous development of China's capital markets, earnings management of listed companies growing more frequent and expansive, The earnings management comes to be an important issue which cannot be ignored by China's administration of accounting and capital market. The study of earnings management and its binding mechanism is important for improving accounting standards and capital market supervision system. In this regard, scholars have carried out numerous studies, and practitioners are constantly sewn up law and control measures for earnings management. Combined with foreign research results and practical experience, some mechanism of earning management-the capital market system causes, listed company executives bonuses motivation, debt covenants motivation, politic cost drivers, have already been carried out and confirmed by a lot of evidences, and they have already been applied in supervision practice. However, what is the relationship between the accounting earnings tax factors and earnings management? Is Tax management the motive for earnings management?
In this regard, foreign studies have two views and relevant evidence. One view is that tax avoidance is an important motivation for the earnings management of a listed company; a listed company can use surplus tax revenue to achieve the best interests; the other view is tax avoidance is not the main motivation earnings management, earnings management of a listed company is not just for tax revenue potential gains, on the contrary, they will not hesitate to take the corresponding tax expense for the potential benefits [1-2] In the emerging and transitional Chinese capital market, listed companies tend to exaggerate there earnings for placement of shares, and tax avoidance motive made companies to under-report earnings, in this dilemma, How do Chinese listed companies? Will the balance tilt to the tax? Can Tax burden as a tool for detecting earnings management?

Study of this issue will help us to understand the earnings management and tax behavioral of china's listed companies. However, so far, most of the earnings management literatures ignore this tax factor for earning management, and the research on Chinese capital market is weak; cannot meet the regulatory decision-making practices and the needs of investors [3]. This work will base on China's market characteristics and institutional characteristics [4], using accounting errors data to find the relationships between earnings management and tax burden, trying to deepen the understanding and detecting earning management by using tax tools, providing experience and evidence for making capital market decisions about relevant aspects [5].

\section{LIPSCHITZ CONTINUITY THEORY AND ALGORITHM}

In mathematical analysis, Lipschitz continuity, named after Rudolf Lipschitz, is a strong form of uniform continuity for functions. Intuitively, a Lipschitz continuous function is limited in how fast it can change: there exists a definite real number such that, for every pair of points on the graph of this function, the absolute value of the slope of the line connecting them is not greater than this real number; this bound is called the function's "Lipschitz constant" (or "modulus of uniform continuity") [6].

In the theory of differential equations, Lipschitz continuity is the central condition of the Picard-Lindelöf theorem which guarantees the existence and uniqueness of the solution to an initial value problem. A special type of 
Lipschitz continuity, called contraction, is widely used in the Banach fixed point theorem [7].

Given two metric spaces $\left(X, d_{X}\right)$ and $\left(Y, d_{Y}\right)$, where $d_{X}$ denotes the metric on the set $\mathrm{X}$ and $\mathrm{d}_{\mathrm{Y}}$ is the metric on set $\mathrm{Y}$ (for example, $\mathrm{Y}$ might be the set of real numbers $\mathrm{R}$ with the metric $d_{Y}(x, y)=|x-y|$, and $X$ might be a subset of $\left.R\right)$, a function $\mathrm{f}: \mathrm{X} \rightarrow \mathrm{Y}$ is called Lipschitz continuous if there exists a real constant $K \geq 0$ such that, for all $x_{1}$ and $x_{2}$ in $X$, then we have:

$$
d_{Y}\left(f\left(x_{1}\right), f\left(x_{2}\right)\right) \leq K d_{X}\left(x_{1}, x_{2}\right)
$$

Any such $\mathrm{K}$ is referred to as a Lipschitz constant for the function $\mathrm{f}$. The smallest constant is sometimes called the (best) Lipschitz constant; however in most cases the latter notion is less relevant. If $\mathrm{K}=1$ the function is called a short map, and if $0 \leq \mathrm{K}<1$ the function is called a contraction.

The inequality is (trivially) satisfied if $\mathrm{x} 1=\mathrm{x} 2$. Otherwise, one can equivalently define a function to be Lipschitz continuous if and only if there is a constant $K \geq 0$ such that, for all $\mathrm{x} 1 \neq \mathrm{x} 2$, we have:

$$
\frac{d_{Y}\left(f\left(x_{1}\right), f\left(x_{2}\right)\right)}{d_{X}\left(x_{1}, x_{2}\right)} \leq K
$$

For real-valued functions of several real variables, this holds if and only if the absolute value of the slopes of all secant lines is bounded by $\mathrm{K}$. The set of lines of slope $\mathrm{K}$ passing through a point on the graph of the function forms a circular cone, and a function is Lipschitz if and only if the graph of the function everywhere lies completely outside of this cone, which is shown in "Fig. 1".

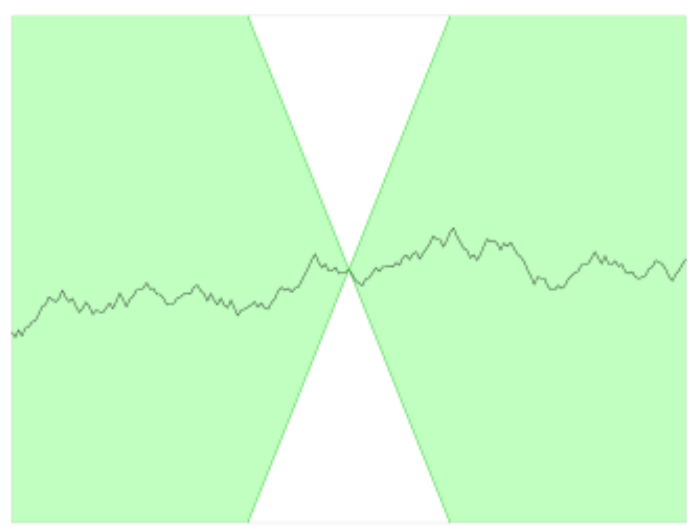

Fig. 1. The conditions for Lipschitz continuity.

a. For a Lipschitz continuous function, there is a double cone (shown in white) whose vertex can be
translated along the graph, so that the graph always remains entirely outside the cone.

A function is called locally Lipschitz continuous if for every $\mathrm{x}$ in $\mathrm{X}$ there exists a neighborhood $\mathrm{U}$ of $\mathrm{x}$ such that $\mathrm{f}$ restricted to $\mathrm{U}$ is Lipschitz continuous. Equivalently, if $\mathrm{X}$ is a locally compact metric space, then $\mathrm{f}$ is locally Lipschitz if and only if it is Lipschitz continuous on every compact subset of $X$. In spaces that are not locally compact, this is a necessary but not a sufficient condition.
More generally, a function $\mathrm{f}$ defined on $\mathrm{X}$ is said to be Hölder continuous or to satisfy a Hölder condition of order $\alpha>0$ on $\mathrm{X}$ if there exists a constant $\mathrm{M}>0$ such that

$$
d_{Y}(f(x), f(y)) \leq M d_{X}(x, y)^{\alpha}
$$

For all $\mathrm{x}$ and $\mathrm{y}$ in $\mathrm{X}$. Sometimes a Hölder condition of order $\alpha$ is also called a uniform Lipschitz condition of order $\alpha>0$. If there exists a $K \geq 1$ with

$$
\frac{1}{K} d_{X}\left(x_{1}, x_{2}\right) \leq d_{Y}\left(f\left(x_{1}\right), f\left(x_{2}\right)\right) \leq K d_{X}\left(x_{1}, x_{2}\right)
$$

Then $\mathrm{f}$ is called bilipschitz (also written bi-Lipschitz). A bilipschitz mapping is injective, and is in fact a homeomorphism onto its image. A bilipschitz function is the same thing as an injective Lipschitz function whose inverse function is also Lipschitz. Subjective bilipschitz functions are exactly the isomorphism of metric spaces [8-9].

\section{StatisticAl ANALYSES}

To overcome the defects in existing literature, this sample design and the need to achieve a surplus on the inflated surplus of these inflated to bear the precise measure of the additional taxes and fees. Accounting errors listed companies in China just to meet this requirement. First, the accounting errors mean that the company has taken inappropriate accounting policies and methods, regardless of its cause, changing earnings means earnings management, thus does not require subjective judgments, the study will overcome arbitrary or speculation; second, the original sample companies must disclose their tax surplus, but also disclosed accounting errors and earnings after tax, which provides accurate and objective measure about the inflated earnings and earnings for these inflated incurred Additional taxes and fees.

In this paper, we take companies which are listed in the Shanghai Stock Exchange from 2008 to 2012 and reported related to accounting errors as sample, for each company, we hand-collected and compiled in the Shanghai Stock Exchange issued a "notice of correction of accounting errors" (hereinafter referred to as "Notice"). "Notice" is given for the stock adjustment behavior of listed companies' summary accounting records, and describes the specific adjustments of the company and adjusted results.

Sample selection process is as follows, from January 2008 to October 2012, a total of 125 times published notice of the company accounting errors, of course, this does not mean that all 125 sub-companies evidently tend to deliberately fraud, therefore, we delete the nine times which objective reasons to accounting errors are given, leaving 119 sub-companies; remove four times the data incomplete samples, and leave 115 companies as samples, and received these company's accounting error correction data. "Table I" summarized the sample company selection process. 
TABLE I.

The SAmple Company Selection Process

\begin{tabular}{|l|l|}
\hline \multicolumn{1}{|c|}{ Item } & Number \\
\hline $\begin{array}{l}\text { from January 2008 to October 2012, companies which } \\
\text { issued a report on the company accounting errors on the } \\
\text { official website of Shanghai Stock Exchange }\end{array}$ & 125 \\
\hline $\begin{array}{l}\text { eliminate: relevant evidence showed that the correction of } \\
\text { errors caused by inadvertent errors and the amount of the } \\
\text { accounting records is small }\end{array}$ & 6 \\
\hline eliminate: data arc incomplete and cannot be calculated & 4 \\
\hline sample companies & 115 \\
\hline
\end{tabular}

For each sample company, we collected the original file of annual disclosure reports and connection of accounting errors related documents, and analyzed the accounting methods related to annual accounting earnings accounting errors. In the company inflating earnings, The means including "fictitious income", "low total cost/costs", "High total inventory", "buying consolidated accounting manipulation," "undue cost of capital" and "tax evasion", "improper revenue recognition," false assets other than inventory, non-monetary asset exchange", etc.. "Table II" reflects the proportion of these means.

TABLE II. The CONSTITUTION OF THE SAMPLE

\begin{tabular}{|l|l|l|}
\hline \multicolumn{1}{|c|}{ Earnings Management } & Number & Ratio(\%) \\
\hline Fictitious revenue & 4 & 3.57 \\
\hline Low total cost/expenses & 47 & 41.96 \\
\hline High total stock & 3 & 1.79 \\
\hline $\begin{array}{l}\text { to purchase consolidated accounting } \\
\text { manipulation }\end{array}$ & 9 & 8.04 \\
\hline Improper capitalization of costs & 8 & 7.14 \\
\hline Evasion tax & 29 & 25.89 \\
\hline Improper revenue recognition & 9 & 8.04 \\
\hline False statement of assets other than inventory & 3 & 2.69 \\
\hline Non-monetary assets & 1 & 0.89 \\
\hline $\begin{array}{l}\text { The company reported earnings of high } \\
\text { frequency }\end{array}$ & 112 & 100 \\
\hline
\end{tabular}

Overall 115 valid samples inflated profits 1,001,987,122 yuan, an average of each sub-sample of the company inflated profits 8,712,931.50 yuan, of which the company inflated the median profit 3,694,081.71 yuan. The company inflated earnings were inflated profits $1,834,652,178$ yuan, virtual cut earnings by the company were false profits $832,665,056$ yuan. For the tax situation, 115 samples of the companies involved in tax adjustments is $43,37.39 \%$ of the total sample, the overall total evade tax $34,552,642$ yuan. In the company relate to tax adjustments, 33 less paid the tax (28.7\%), less total tax $112,155,092.3$ yuan, merely 10 paid more tax (8.7\%), a total of more taxes $77,602,450.46$ yuan. While the other 72 companies no tax adjustment. Thus, 85 companies inflated earnings, the companies paid higher taxes only 10 , indicating that most of the earnings management of listed companies has not brought additional tax revenue, most of the company pay tax with the Company's actual taxable profits, but reported higher inflated profits. On the whole, 115 samples of inflated profits $1,001,987,122$ yuan, but less $\operatorname{tax} 34,552,642$ yuan. Therefore, on the whole, China's listed companies' earnings management have not brought the increase in taxes, on the contrary, through appropriate measures, to achieve inflated earnings and reduce the tax burden "double harvest" situation, there is no surplus management and tax burden weighing difficulties. Its regulatory implications of a very rich, further analysis is under below.

Evade tax 34,552,642 yuan. In the company relate to tax adjustments, 33 less paid the tax $(28.7 \%)$, less total tax $112,155,092.3$ yuan, merely 10 paid more tax $(8.7 \%)$, a total of more taxes $77,602,450.46$ yuan. while the other 72 companies no tax adjustment. thus, 85 companies inflated earnings, the companies paid higher taxes only 10 , indicating that most of the earnings management of listed companies has not brought additional tax revenue, most of the company pay tax with the. Company's actual taxable profits, but reported higher inflated profits. On the whole, 115 samples of inflated profits 1,001,987,122 yuan, but less tax 34,552,642 yuan. Therefore, on the whole, China's listed companies' earnings management have not brought the increase in taxes, on the contrary, through appropriate measures, to achieve inflated earnings and reduce the tax burden "double harvest" situation, there is no surplus management and tax burden weighing difficulties. Its regulatory implications of a very rich, further analysis is under below.

From "Table III" can be clearly seen that most of the earnings management of the company did not bear the additional tax burden, on the contrary, some companies had inflated earnings by a false tax return, which accounts for $31.8 \%$ of companies inflated surplus. These companies on the one hand inflated earnings; on the one hand reduce the tax return in order to achieve the dual income of earnings management and tax management. Of course, this may be because in the process of earnings management these companies did not consider the factors of tax revenue. The proportion of companies paid less tax in the virtual surplus' companies is not high, only by these company's $25.0 \%$, no tax adjustment companies accounted for $45.8 \%$, lower than the company the inflated earnings $64.7 \%$ ratio. In the virtual reduced earnings companies, there are also the cases of inflated tax, accounting these company's $29.2 \%$.

TABLE III. The EARnings MANAGEMENT AND TAX AdJUSTMENTS

\begin{tabular}{|c|c|c|c|c|c|c|c|}
\hline \multicolumn{2}{|c|}{$\begin{array}{c}\text { Tax adjustment to earnings } \\
\text { management }\end{array}$} & \multicolumn{6}{|c|}{ the situation of tax adjustment } \\
\hline & $\begin{array}{l}\text { No. of } \\
\text { Sample }\end{array}$ & $\begin{array}{l}\text { No. of Company } \\
\text { paying less tax }\end{array}$ & $\begin{array}{l}\text { Less corporate } \\
\text { tax rate }(\%)\end{array}$ & $\begin{array}{l}\text { No. of None } \\
\text { adjustment }\end{array}$ & $\begin{array}{l}\text { Proportion of None } \\
\text { adjustment } t(\%)\end{array}$ & $\begin{array}{c}\text { No.of } \\
\text { paying } \\
\text { more taxes }\end{array}$ & $\begin{array}{l}\text { Proportion of paying } \\
\text { more taxes }(\%)\end{array}$ \\
\hline Inflated earnings & 85 & 27 & 31.8 & 55 & 64.7 & 3 & 3.5 \\
\hline Reduced earnings & 24 & 6 & 25.0 & 11 & 45.8 & 7 & 29.2 \\
\hline None of the adjustment & 6 & 0 & 0 & 6 & 100 & 0 & 0 \\
\hline Total & 115 & 33 & 28.7 & 72 & 62.6 & 10 & 8.7 \\
\hline
\end{tabular}


The above data analysis shows that there is a tendency that companies virtual inflated earnings and virtually minus tax, or earnings management and tax management practices are two independent acts, the company earnings management is likely the process does not consider tax factors. In short, the company is almost impossible to carry out the virtual in order to reduce the tax cut the surplus earnings management, that is, in our current institutional environment; tax avoidance is not the motivation for earnings management.
"Table IV" gives the earnings management and tax adjustments of specific statistical data; From "Table IV" whether virtual inflated earning or virtual minus profitable companies, there is the phenomenon of virtual minus tax charges, regardless of the median number and the average number of virtual minus tax fees were clear showed this phenomena, resulting in the overall sample which showed the false tax reduction.

TABLE IV. THE EARNings MANAGEMENT AND TAX STAtistics (Unit: Yuan)

\begin{tabular}{|l|l|l|l|l|}
\hline $\begin{array}{c}\text { EM and additional } \\
\text { tax }\end{array}$ & $\begin{array}{c}\text { Average amount of } \\
\text { inflated earning }\end{array}$ & $\begin{array}{c}\text { Median amount of } \\
\text { inflated earning }\end{array}$ & $\begin{array}{c}\text { Average amount } \\
\text { of additional tax }\end{array}$ & $\begin{array}{c}\text { Median amount of } \\
\text { additional tax }\end{array}$ \\
\hline Overall of samples & 8712931.5 & 3694081.70 & 300457.80 & 1233288.00 \\
\hline Inflated earnings & 21584143.00 & 12060010.00 & 1223921.2 & 2171020.5 \\
\hline Virtual cut earnings & -34694377.30 & -2931720.00 & 2895027.50 & 824057.50 \\
\hline
\end{tabular}

Therefore, the company there is a tendency to false tax charges. From earnings management situation, regardless of the overall sample mean or median earnings have shown inflated, which is listed company inflated profits through earnings management consistent with commonsense. In the company inflated earnings, the tax reduction phenomenon is very obvious false, indicating that either the company during the existence of earnings management, but also reduce the tax burden by means of false, in order to achieve the double earnings management and tax reduction goals, or even false reduce the tax burden in order to improve earnings, reduce the tax burden to the false earnings management as an important means; or earnings management and tax management are two independent acts, the company earnings management process does not consider tax factors, while in tax administration also does not exist will not bear any additional tax the profits. In the company of virtual minus surplus, while the overall situation there is less tax imaginary, but did not achieve tax reduction and the virtual change in the same proportion of profits.

Accordingly, the consolidated above, be sure that the institutional environment in China, the company is almost non-existent earnings management and tax management dilemma decision-making situations, tax avoidance is not the motivation for earnings management, earnings management cannot consider tax factors, Excluding a tax return is also free to factor in earnings management, corporate accounting practices lack the necessary tax constraints. On the contrary, false tax burden may be reduced to a lower surplus means inflated.

\section{CONCLUSION}

The relationship of earnings management and the tax burden the most basic and important issue of capital market supervision and coordination of tax fee and accounting. Is tax burden management the motive for earnings management? What is the relationship? In the obvious characteristics of emerging and transitional capital market, the placement of shares of listed companies qualify for the pursuit of such motives tend to exaggerate the potential surplus, and tax avoidance motive of the company reported lower earnings in this dilemma, the value of listed companies in China affiliation? The balance will tilt to the tax? Difference between tax and can detect earnings management as a tool? However, so far, most of the earnings management literature ignores this factor tax for capital market research in China is weak, cannot regulatory decision-making practices meet and needs of investors. This will be based China's market characteristics and institutional characteristics, the use of accounting errors data, earnings management and tax burden study the relationship between earnings management in order to deepen the understanding and detection tools, and relevant aspects of the capital market decisions experience and evidence.

Study found that the basic objective of earnings management is inflated earnings, accounting for $73.9 \%$ of sample companies, which domestic and international capital markets law consistent with earnings management. Whether or virtual inflated earnings profitable companies, there is the phenomenon of false tax charge, resulting in the overall sample showed false tax cut. In the company inflated earnings, taxes, the phenomenon of virtual reduction is very obvious reduction in the surplus of virtual companies, while the overall situation there is less tax imaginary, but did not achieve reduction of profits tax and the virtual change in the same proportion. Therefore, most of the earnings management of the company did not bear the additional tax burden on the contrary; some companies have inflated earnings by a false tax return, the company is almost impossible to carry out the virtual in order to reduce the tax cut the surplus earnings management, namely, the existing institutional environment in China, the company is almost non-existent earnings management and tax management dilemma decision-making situations, tax avoidance is not the motivation for earnings management, earnings management cannot consider tax factors, tax returns are also free to remove surplus management factors, the company lacks the necessary tax accounting practices restraint. On the contrary, false tax burden may be reduced to a lower surplus means inflated.

\section{REFERENCES}

[1] E.Biham and A.Shamir. (1993). A Differential Cryptanalysis of the Data Encryption Standard. Springer-Verlag, pp. 126-129. 
[2] Mitsuru Matsui. (1994). The first experimental cryptanalysis of the data encryption standard. In Yvo G.Desmedt, editor, Proceedings CRYPTO 94, Lecture Notes in Computer Science No. 839, pp. 1-11.

[3] Biddlc, G. (1980). Accounting methods and management decisions: The case of inventory costing and inventory policy. Accounting Research (Supplement), pp. 235-280.

[4] Dechow, P., R. Sloan, and A.Swccncy. (1996). Causcs and consequences of comings manipulations: An analysis of firms subject to enforcement actions by SEC. Contemporary Accounting Research,13(1), pp. 17-36.

[5] Erickson, M., M. Hanlon, and E. Macaw. (2004). How much will firms pay for earnings that do not exist? Evidence of taxes paid on allegedly fraudulent carvings. The Accounting Review, 79(2), pp: 387-408.

[6] Glcason, c. and L. mills. (2007). Materiality and continent tax liability reporting. The Accounting Review,77, pp. 317-342.

[7] Phillips.J., M. Pincus, and S. Rego. (1978). Earnings management: New evidence based on the deferred tax expense. The Accounting Review, pp. 491-522.

[8] Shaekel ford.D., And T. (2004). Shelving, Empirical tax research in accounting, Journal of Accounting and Economics,31, pp. 321-387.

[9] Xu Ke, Liu Yaxiao, Liu Weidong. (2001). The Design and Implementation of Security Access Proxy in Database application System. Computer Engineering and Application, 1, pp. 105-107. 